\title{
Key Positions about the Economic Legacy of Aristotle
}

\author{
Hernán Gabriel Borisonik \\ Dept. of Political Theory, University of Buenos Aires \\ Pres. José Evaristo Uriburu 950 - 6th floor (C1114AAD) Buenos Aires, Argentina \\ Tel: +5411-4508-3815Ｅ-mail: hborisonik@sociales.uba.ar
}

Received: May 19, 2016 Accepted: July 1, 2016 Published: July 28, 2016

doi:10.5296/jpmr.v2i2.9492 URL: http://dx.doi.org/10.5296/jpmr.v2i2.9492

\begin{abstract}
This article describes the main theses of some of the most celebrated authors that have explored the meaning of economy in Aristotle in Modern times. Firstly, the debate between the "modernist" and "primitivist" doctrines, which led to the subsequent discussion will be reviewed. Then, the ideas of Karl Marx, Joseph Schumpeter, Karl Polanyi and Moses Finley will be discussed. The object of this work is to show the interpretative debate and not to study Aristotelian economic ideas themselves.
\end{abstract}

Keywords: Economy, Aristotle’s legacy, Marx, Schumpeter, Finley, Polanyi

\section{Foreword}

In the nineteenth and twentieth centuries a number of authors argued that there was an unbridgeable distance between Greece and Modern times and that economic analysis was irrelevant in the Ancient world. Max Weber and his disciple Johannes Hasebroek defended that idea. Other authors, who studied or criticized the Aristotelian economic conceptions, made the mistake of applying economic concepts of their time to classical Greece. Therefore, some scholars, like Moses Finley, said that to translate "oikonomia" or "oikonomike" as "economy" was a serious anachronism.

This article describes the main theses of some of the most celebrated authors that have explored the meaning of economy in Aristotle in Modern times. Firstly, the debate between the "modernist" and "primitivist" doctrines, which led to the subsequent discussion will be reviewed. Then, the ideas of Karl Marx, Joseph Schumpeter, Karl Polanyi and Moses Finley will be discussed. The object of this work is to show the interpretative debate and not to study Aristotelian economic ideas themselves. 


\section{The Modernist-primitivist Debate}

The first modern theory about ancient economy was developed by Johann Karl Rodbertus in 1865. His ideas aroused a strong controversy, initiated by the investigations of Karl Bucher and Eduard Meyer and continued by Michael Rostovtzeff and Max Weber. That intense debate between "primitivists" (led by Rodbertus and Bucher) and "modernists" (followers of Meyer and Rostvztzeff) was tempered, but not surpassed, by Weber's General Economic History, which did not provide a theoretical scheme to explain the economic mechanisms but inspired younger thinkers as Polanyi and Finley.

The questions that were at the center of the debate were the following: "Had the old economy showed some level of development or was it essentially primitive?", "Were 4th and 5th centuries B.C. a time of national and international trade, industrial progress growing and developing market or had not passed the closed domestic economy?”, in brief, was economic life more agricultural or industrial? And was trade limited or important?

The first of these two opposing positions argued that there was market development in Antiquity, so it was possible to draw analogies with the present (as defended for the first time by Friedrich Oertel, and called "positive" theory). The second one, which argued that the old economic world is not comparable with today's world, was called "negative" by Oertel and "primitivist" by Hasebroek.

The modernists argued that currency had great impact on past transactions and it was not possible to understand the Greek economy if unaware of the existence of surplus production sold in rudimentary form, but generated by industry and traded internationally.

Primitivists claimed that Greek domestic economy was based on relations of reciprocity or redistribution among family members and among citizens or freemen. While accepting that the existence of the currency was a historically proven fact, they downplayed its use because it was not related to the Greek autarkic ideal.

In a suggestive article that put an end to the discussion, Edouard Will (1954) criticized both schools and postulated that modernists -in their eagerness to project modern categories on to old economy- and primitivists -who denied some existing historical events in ancient Greece- had failed in their attempt to understand the issue in its substantive dimension.

Let us take a look on that theoretical controversy, starting with Johann Rodbertus (1899). The wake left by this author was to separate old and modern economic systems based on taxation. His scheme included the idea of passing from a "natural economy" to a "monetary economy" and the advent of a totally different social structure. Rodbertus did a historical study of the polis, but his outline was totally abstract. However, Rodbertus showed that different uses of money and he found that currency was serving a social function that did not receive due attention of his disciples or his contemporaries.

Even before Rodbertus there were two streams about the relationship between antique and modern economies. Bücher (1893) elaborated a general theory of economic development from primitive times, which did not equate ancient primitivism. He argued that, until the 11th 
century, the economy had not passed domestic and closed nature (i.e., subsistence economy), but he denied the importance of trade, industry and coinage. In 1895, Meyer criticized that theory and said that late Antiquity was essentially "modern”, based on market development and institutional money. The problem with this position is that it tends to equate market to Modernity.

Max Weber (1974) attempted to develop a moderate theory, rejecting both approaches and recognizing some analogies between ancient and modern economies, although he attributed the former a political-military leadership of society, and the latter a market design.

Rostovtzeff (1941) was part of the debate, responding to Marx that the struggles and revolutions of ancient Greece were not comparable with class struggles. In addition, he argued that commercial development that accompanied the collapse of the polis differed only in quantity (not quality) of the modern one. For Rostovtzeff, as for Oertel, the development of the ancient world was comparable to the modern world, and he considered erroneous any attempt to defend the primitivist vision. In that regard, he noted that in Greece the economy was not a completely closed or domestic one, due to the influence of Oriental empires.

We will now see four of the most important hermeneutics on the Aristotelian economic ideas, which marked fundamental ways to the current interpretations.

\section{Karl Marx}

Marx spent several years studying (and translating) part of the Aristotelian work. In the third section of the first volume of Das Kapital, Marx says that Aristotle's genius was to have discovered a relationship of equality in the expression of the value of goods. Although, he concludes that Aristotle failed in his analysis due to historical limits, since Greek society was based on slave.

While the structure of his argument on commensurability is practically a calque of the Aristotelian structure, Marx transforms it when he postulates that the secret of the value expression (equality and equivalence of all human works) could only be revealed when the concept of human equality had the strength of a widespread preconception (something like a habit, a nomos). But that could only happen in a society different from Aristotle's one.

It is well known, nevertheless, that natural inequality among men was part of Aristotle's thought. That idea is present in his analysis of friendship in the Nicomachean Ethics, and in the definition of slavery in Politics. However, his vision of exchange expressly corresponds to freemen ("the architect" and "shoe" are free men, not slaves).

According to Marx, the value of a commodity is determined by a common element in the objects exchanged. The search for that element (or common substance) leads him to assume an underlying essential equality in the objects exchanged. Correspondingly, for the exchange to be possible there must be a quantifiable measure that makes things commensurable. But this does not equate to the need or utility (as for Aristotle), but is only noticeable when the observable characteristics of the goods are abstracted.

What all interchangeable objects have in common, beyond its use value, and that transcends 
the sensible qualities, is, in his eyes, the fact of being products of human labor. Work is, therefore, that substance the universal measure that determines the proportions of the exchange. In general, work is, in a physiological sense, an expenditure of human labor power, perceived by the senses. That is what Marx defines as "simple and socially necessary abstract labor", i.e. the common, crystallized substance that makes possible that significantly different things can relate one another as commensurable magnitudes.

In Chapter IV of Capital, Marx retakes some Aristotelian notions to criticize the inversion of means and ends in the capital formation and accumulation. In such passages, Marx quotes Aristotelian criticism of the illegitimate chrematistics contained in Politics. The kind of trade, where money is used to obtain a commodity, which is then sold for a greater sum (condemned by Aristotle), is taken up by Marx to differentiate the direct formula of the movement of goods (or simple circulation, M-D-M) and the general formula of capital (D-M-D'), to which the unnatural chrematistics movement resembles.

Aristotle abhors the most reprehensible form of exchange, which is lending money at interest [tokos]: "usury is very justifiably detested, since it gets wealth from money itself, rather than from the very thing money was devised to facilitate. For money was introduced to facilitate exchange, but interest makes money itself grow bigger” (Politics, 1258 b 1-7).

Marx compares that with the "usurer capital," represented by the formula D-D'. This form does not aim the appropriation of use values, or meet a need, but represents something "uneconomical" in an Aristotelian sense: to speculate and make money from money. This is the purpose of the usurer capital and the unlimited chrematistic in their relentless pursuit of profit.

It is clear that the treatment of Marx to Aristotle's economic theory is not absolutely exhaustive nor deep. But he drew attention to the importance of these writings to understand economic phenomena, beyond the differences of historical context.

\section{Joseph Schumpeter}

With a much less complex than Marx's approach, Joseph Schumpeter wrote in 1959 his History of Economic Analysis. In that book he distinguished the "economic thought" from the "economic analysis". The first one consists of the opinions on economic issues prevailing in a time and in a certain society, and belongs more to the economic history than the history of economics. On the other hand, economic analysis is the result of a scientific effort to understand the economic phenomena. Thus, according to Schumpeter, the history of economic thought began with the records of ancient civilizations, and the history of economic analysis originated in Greece.

Schumpeter believed that within the Greek economic thought there are some signs of scientific effort in the works of Plato and Aristotle. But Plato has not found, even in rudimentary form, an "economic analysis". What differentiates both thinkers is the analytical intention, absent in Plato and evident in Aristotle. Anyway, for Schumpeter, the work of Aristotle and his interest in social phenomena, belong to economic sociology or political sociology. 
Schumpeter developed his critique using three concepts: value, money and interest. As for the conception of value in Aristotle, he found a "weakness", his concern for justice in price formation would have diverted the interest of the philosopher analytical aspect. Some fragments of the Nicomachean Ethics, V, 5, would show that Aristotle tried a conclusive analysis, without success (Schumpeter, 1959: 88).

On the subject of money, Schumpeter said that Aristotle's observations are the basis of all analytical work on the monetary sphere. According to him, the Aristotelian monetary theory prevailed until the late 19th century. He noted that three out of the four functions of money that are normally mentioned on the digests had been outlined by Aristotle: medium of exchange, measure of value and reserve of value. The fourth function (deferred payments pattern) could never be developed in the context of the polis, because although Schumpeter did not clarify it, that practice did not exist in the ancient world. However, for Schumpeter, Aristotelian writings about money were defective because Aristotle was unable to think about that abstractly (i.e., separate from politics and ethics).

In his analysis about lending with interest, Schumpeter believed that Aristotle accepted the empirical fact of interest on borrowing money and saw no problem in that practice. According to him, Aristotle never classified loans according to the designs that could be used, nor observed that a loan for consumption was, in fact, very different to a finance maritime trade. Anyway, he condemned interest (which he equated in all cases to usury), because there was no justification for money, mere instrument of exchange, would increase going from hand to hand. Aristotle never developed a theory of interest and only the scholastics raised the first positive theory on the subject.

Schumpeter saw in Aristotle the first author who made "economic analysis" but was conditioned by an ideological vision. According to the German author, theoretical research in the resource Aristotelian repeatedly perceived elements that are not strictly analytical, but ethical and metaphysical. Therefore, the economic analysis of Aristotle would not have overcome the common sense of his time or faced slavery.

What surprises Schumpeter on Aristotle's analysis is that he glimpsed some fundamental analytical distinctions, even without "overcoming" the idea of natural slavery. For Schumpeter, the requirement to develop an analytical economy is free itself from all ideology and, thus, purge political economy of any intrusion of value judgments, to make it a special knowledge supported by analytical instruments.

We can not close this chapter on Schumpeter without pointing out that he made some fundamental mistakes. Mainly, he failed to distinguish between empirical analytical arguments. For example, he did not notice the difference between what happens "first" at the level of experience, of what is "above" by nature. Perhaps this is due to lack of understanding of the Aristotelian separation between philosophy (speculative science on what is necessary) and practical science (which studies contingent things).

Although Schumpeter saw in Aristotle a sensible thinker, as regards the economy, he did not understand that in its meaning horizon, ethics, politics and economy were parts of a whole 
that was the dynamic reflection of reality. Therefore, he demanded Aristotle to reach conclusions that could not be reached, not for lack of objectivity or analytical ability, but because of his theoretical and methodological ways.

\section{Karl Polanyi}

The main theoretical concern during the first half of the nineteenth century was to find the origins of the capitalist economy, to understand its operation, development and possible mutation or disappearance. Karl Polanyi, following Marx on that, denied to the political economy of his time the ability to explain the profound logic of capitalism.

Throughout his historical research, Polanyi found three types of economic mechanisms or relationships: reciprocity, redistribution and exchange. Each system varies depending on the organization of the different social institutions and these three mechanisms. Polanyi examined the effects of various forms of organization that were observed in history and found that in all societies there were elements of these three mechanisms, although one was dominant and subordinate the others.

In his article "Aristotle discovers the economy," Polanyi showed that the influence of Aristotelian thought in medieval economy was as important as Adam Smith's and David Ricardo's ideas would exert in the economy of the 19th century. According to this thinker, with the emergence of a large scale market system, and the "classical" schools of economic thought, Aristotle's doctrines were forgotten. And not only that. Modern economists seem to believe that all that Aristotle wrote about economy suffered from great weaknesses. Thus, sections of the corpus aristotelicum dealing with economic issues are often ignored or poorly studied. Something remarkable for an author of such a great influence, which laid the foundation for almost all disciplines of Western science.

Instead, Polanyi proposed an interpretation of great relevance and depth, because it takes into account not only the written word but also the context in which Aristotle elaborated his ideas, and shows that his comments on the economy should not be underestimated. He also noted a key defect in the majority of modern economists: they do not realize that Aristotle's remarks on economy contained all the inherited doctrinal body of classical Greece thought.

According to Polanyi, the commercial impulse was born in the oldest cultures as a result of interest in importing goods (while the interest of capitalist societies focuses on export). Trade consists of four elements: people (the merchant may have different motivations, such as status or benefit, depending on the place that gives the society they live), property (originally, trade was specific and not general, that is, exchanged goods were very specific), routes and bidirectional relationships.

For Polanyi, the currency (same as trade) is an independent factor in the market, given its uses and main functions are to be a method of payment and medium of exchange. And he defines the market as a reciprocal movement of appropriation of goods between different hands, at fixed or negotiated rates.

According to this argument, Aristotle did not try to analyze market mechanisms, because he 
did not know a developed market. What he did was theory an elaborated at the dawn of the commercial market, when it was appearing in an incipient form. But despite the intense commercial activity and monetary fairly advanced uses (especially in Athens), business life was still in its timid beginnings.

The thesis of Polanyi is that one of difficulties in the interpretation (and differentiation between the Aristotelian concept of economy and the modern "economic science") is the lack of distinction between a "conditional status" and an "autonomous status" of the economy on society.

According to Polanyi, when Aristotle was referring to economic issues, he sought to emphasize its links to the whole society. His main problem was to relate the origin and functioning of institutions with society. Its concepts-of-reference were community self-reliance and justice. In the interpretation of Polanyi, both at the oikos and the polis a kind of specific philía of koinonia existed, without which the community could not survive. That philía was expressed on reciprocity, namely, the willingness to share social charges. All that was needed for the preservation of the community, including self-sufficiency, was considered natural and intrinsically good. In this context, autarchy was the ability to survive without external resources. Which guaranteed justice in the distribution of privileges of life and the regularization of mutual services was judged as good, as it was necessary for the life of the community. In short, the community, self-reliance and justice are the foundation of Aristotelian thought on all economic issues.

One of Polanyi's merits in his analysis of Aristotelian economic texts is to have considered the context of the Nicomachean Ethics, where the Stagirite began to think about fair trade and the use of money. He was also the first to note that the description of chrematistics had two faces: on the one hand, the reference and subordination to the administration of the oikos or oikonomía; on the other hand, the art of acquiring unlimitedly beyond mere subsistence. Marx made a similar interpretation, although he overlooked the Nicomachean Ethics, so natural chrematistics was confused with oikonomía.

Polanyi's interpretation is contrary to the position of Schumpeter, who found in Aristotle's work only pompous, mediocre, rudiments and common sense in regards to economic thought. Polanyi, however, showed that observations made by Aristotle were fundamental for posterity, both for its privileged geographical and historical position, as for the brightness with which he developed his ideas.

\section{Moses Finley}

One of the most prominent Hellenists of the 20th century, Moses Finley, intervened in the dispute between modernism and primitivism (taking the side of the latter). His analysis of economic Aristotelian writings was made from a historical materialist perspective. One of his main thesis is that none of the writings of classical antiquity economics can be considered "economic analysis".

His criticism was directed mainly to Schumpeter's comments on the economic analysis in Aristotle. Surprisingly, it took the definition of that author without modifying anything. 
Finley distinguished economic analysis from comments or descriptions of economic activities. He tried to differentiate these two processes that shaped the concept of economy.

After examining some passages of Nicomachean Ethics V,5, Finley concludes that Aristotle had no attempt to develop a theory of market prices. According to him, those who did it were the Middle Ages theologians, who laid the foundation of the fair price doctrine. For Finley, Book V of Nicomachean Ethics is a reflection on the fairness of trade within the community, namely, between free and equal individuals living in order to self-sufficiency. Therefore, the gain of money had no place there.

As for Politics I, Finley argued that Aristotle was not intended to examine the rules or mechanisms of trade. On the contrary, he wanted to highlight the unnatural character of commercial profits, which exclude this type of analysis. This interpretation (consistent with his explanation of the restrictive nature of the analysis in Nicomachean Ethics) lead Finley to the conclusion that in the mentioned work there are no trace of economic analysis.

Finley argued that one of the reasons so that one can not speak of "classical antiquity economy" is the lack of physical evidence or documents proving economic interdependence in that period. For him, this concept can not be justified by the existence of a close relationship between grain prices (which were negotiated) and the links between poleis. According to Finley, there was no direct link between production and prices, neither in production centers nor in consumption ones.

For Finley, those trying to study the old economy can only investigate its "political history" or "social history" because of the lack of accurate data and the meaning of "economic activities" in such circumstances.

Regarding the case of Aristotle, Finley made some critiques of the Polanyi's interpretation on the historical development of the commercial market and the quantification of economy (according to Finley, Polanyi omitted some treaties and calculations). But Polanyi had a fundamental reason to support his own claims and omit quantification: he considered that only a generalized market economy made possible and necessary economic calculus, in formal and practical levels.

Moreover, in Finley's opinion, it is not possible to speak specifically of "economy" in the ancient Greek world: what abounded were descriptions such as Xenophon's -more like a "manual on the oikos" than a true analysis. While what was called "economy" or "economic science" since the 19th century did not appear in classical Greek writings (as it was scattered and was part of other disciplines), Finley recognizes that the Aristotelian reflections are the highest point for such sort of texts.

However, he notes in Greek thinkers a mentality that pushed to the extreme the notion of what we call Economy, since it was practically the exclusive domain of outsiders (Finley, 1970: 25). In other words, Finley's problem is not to realize the pejorative attitude towards trade and traders did not reflect the centrality that this activity had for the life of the polis. Anyway, Finley studies constitute a major effort to understand the concepts and ideas that nourished categories and uses of the economy in Greece. 
Furthermore, as demonstrated by Scott Meikle, the Athens of the 4th and 5th centuries B.C. was experiencing a series of enormous economic, social and political shifts, among which the most significant was the emergence and development of specific elements linked to the market economy (Meikle, 1979: 57).

It is very difficult to say that Finley saw in the Aristotelian texts something more than a moral condemnation of certain economic practices. This is evident in his conclusions, which suggest that it is not possible to find any analytical content on the economic ideas of Aristotle, but only censure and contempt in face of historical change.

Finley was more interested in fighting the anachronism that some economists' perspectives held (who saw in Aristotle a prototypical version of schools and authors of the 19th and 20th centuries). In that effort, he fell into the traps of Schumpeter, whose conception of the economy he was linked to the positivist tradition.

\section{A Few Final Reflections}

This article has summarized the writings of leading modern authors who analyzed the meaning of the economy in Aristotle. The prolonged debate on that topic began with Marx's observations about the importance of Aristotle's disquisitions about money and the economy. Marx did not discuss whether or not the Stagirite made "economic analysis", but he did show that (and how) Aristotle thought about issues of great importance for the history of political economic thought. He attributed to Aristotle the very first theory of value, which -in his opinion- could not be completed for historical reasons. But beyond the validity of the Marx's observations, it is a fact that these were the starting point for the discussion (among many political, historical and economic thinkers) on the presence or absence of "economic analysis" in the Aristotelian writings.

The biggest problem that display investigations on this problem, and on the former general economy is a lack of consideration of the original meaning of the terms used. The economic vocabulary has been adapted by modern senses, and the terms and archaic concepts have been disassociated from their original meanings. The current concept of "economy" does not match that of oikonomia taken by Aristotle in his Politics. For that reason, some authors analyzed or criticized the Aristotelian economic writings, with a scientific economical perspective which led them to commit certain errors -sometimes very serious ones.

For Schumpeter, Aristotle was an ancient author who laid the rudimentary fundamentals of economic analysis. But after his words, many works on history of economic doctrines examine the thought of the Greek philosopher trying very hard to establish (misleading) analogies between Aristotelian oikonomia and contemporary economy. According to Schumpeter's judgment, the "analytical intention" of Aristotle is doubly uncomfortable: first, his efforts towards "economic analysis" were fragmentary, and can not be compared with his extraordinary contributions in other fields; secondly, his attempts in this field did not produce more than "a decent common sense, prosaic, slightly mediocre, and more than a little pompous" (Schumpeter, 1959: 57).

Schumpeter argued that Aristotle tried to produce "economic analysis" and to make a research 
on the mechanisms of the market and fair prices -thesis shared by Soundek (1952: 47), among others. Schumpeter explained the "failure" of this endeavor based on the ideas of Karl Marx. But in this attempt, Schumpeter did nothing but overextend erroneous arguments:

"Aristotle lived in a society and breathed the air of a civilization to which slavery was essential. However, he also lived in a time when this essential institution was under fire from social critics. In other words, slavery had become a problem. This problem Aristotle attempted to solve by positing a principle that was to serve both as an explanation and as a justification. It stated what he thought was an indubitable fact, the 'natural' inequality of men: by virtue of inborn quality, some men are predestined for subjection, others for rule.” (Schumpeter, 1959: 59)

Based on these heuristic principles, Schumpeter found an embryonic "pure economy" in Aristotle, in his reflections on nature and his ideas about justice, although these concepts are expressed in the ideal of perfect and virtuous life. Economic facts and their relations were examined by Aristotle "in the light of the ideological preconceptions to be expected in a man who lived in, and wrote for, a cultivated leisure class, which held work and business pursuits in contempt and, of course, loved the farmer who fed it and hated the money lender who exploited it.” (Schumpeter, 1959: 60)

Moses Finley, based upon the Weberian thesis focused on the inapplicability of market analysis into the ancient world, argued that none of the writings from classical antiquity on oikonomia is economic analysis in the Schumpeterian sense. His idea was that the terms "economy" and "economic" in its modern sense, are the result of capitalism and can not be applied to other socio-cultural formations, as if the practical attitudes which they involve were innate to man. Thus, Finley was very critical of the theories of some authors of the western economic history (for which bargaining, calculation and search for profit through trade were "natural" activities, who saw a complete continuity between the old and the modern economy and who held that European economic history from the late Middle ages is unique and has no roots in classical Greece at all).

From a different perspective, Polanyi confronted Finley and Schumpeter simultaneously: he claimed that Aristotle had no interest in analyzing "market mechanisms" and never dealt with price formation in a commercial way. However, Polanyi argued (against Finley) that Aristotle saw the birth of the market, and theoretically analyzed the elements of this new form of social relation during the decline of the polis. The market was, as shown by Polanyi, in an embryonic and rudimentary stage, but already had a foundation and a qualitative status comparable to which it would reach twenty centuries later. Noting the germ and birth, Aristotle sensed the complete specimen.

In Polanyi there is a "moralistic" slant that puts Aristotle in a conservative perspective. Perhaps influenced by the anthropological climate of the period (especially by the work of Malinowski about gift in non-capitalist economies), Polanyi turned his attention to show that Aristotle sought to preserve reciprocal relationships, and omitted his attempts to assign an intrinsic or objective value to property: the utility with which each thing contributed to the community. In Aristotle's thought, the strong defense of the polis was not linked to the 
restitution of the gift as a form of exchange, but to a deeper concern for regulating the exchange ratio. That is, the idea of philia was not linked to the return of barter, but rather to find the fairest way to buy and sell goods, in order to achieve a politically active and autarkic life. While Polanyi seems contradictory (he says "Aristotle discovers the economy" because the market was born during his life, but at the same time suggests that he was defending institutions that had vanished at least a century ago), Finley emphasizes too much the moral aspects Aristotelian analysis.

In addition to that, when Finley discusses the meaning of the economy as a modern concept and at the same time argues that the writings from classical antiquity on the subject were never beyond the rudimentary observation, this author highlights a problem of his own conjectures. His refusal to identify an economic analysis Aristotle was motivated by his disagreement with those who thought that in Greece of the 4th century B.C. there was an -even incipient or distantly commensurable-commercial market with the modern one. That is, he deduced that it was not possible to speak of economic analysis in Aristotle because there were no glimpses of a "market economy" (i.e., of capitalism), even in its most elemental state.

But in his argument there is a vague (for not to say contradictory) question: In the debate with his contemporaries he harshly criticized those who found points of comparison between the ancient and modern economies, notwithstanding he made himself such comparisons when he called "primitive" to that economic activities or "rudimentary" to the observations of Aristotle and other Greek thinkers. Although he was not aware of it, these comparative terms stood the modern economy in the place of the canon, the exemplar pattern from which the foregoing economy is judged. If he wanted to point out that the old oikonomia can not be analyzed from the perspective of the modern economy, rather than "primitive" he should have simply called it "Greek economy". Additionally, to say that Aristotle failed to analyze the market mechanism is to admit that there were forms of capitalism at that time. And the same happens when he says he was blinded or disabled by ideological or moral prejudices.

Something similar happens with Marxian approach about the impossibility of Aristotle discovering the true hidden concept of value in the essential equality of human labor. Applying the concept of class to the Greece of Aristotle is, at least, very delicate. This concept divides men by their relationship to the means of production: between those who possess them and those who only have their labor power. That is, those who work versus those living of work of others. Following a mechanical interpretation of the concept of class, slaves and free salaried workers belong to the same class, as well as all working land-owners.

In his research, Aristotle considered the foundations of the polis and politeia, the relations among men, exchange, use and justice. And as for the birth of the market, he was concerned with the regulation of social practices in which currency was essential. In other words, he tried to solve the problem of how to get men to use money as a means for the exchange without being tyrannized by it.

Currently the dominating concept of human is the homo øconomicus, namely of man with a natural inclination to trade, beyond the political, economic and social framework. That vision, 
characteristic of the utilitarian rationality, constantly seeks to find a system (if only in its "potential"). Facing that, a renewed point of view that sees the economy as a social process is required, as attempts to justify a natural economy have not resulted in more fair or equitable societies. In that sense, it would be very healthy to return to the Aristotelian texts, because (although the transformations experienced in Athens during his life are specific in a historical sense) is undeniable that the problems faced by Aristotle are still essential to understand our own context and that maybe his ideas are worth to be heard.

\section{Acknowledgements}

My research is financed by the National Scientific and Technical Research Council (CONICET) of Argentina. I also want to thank the University of Buenos Aires.

\section{References}

Aristotle [Edited by Jonathan Barnes] (1984). Complete Works of Aristotle, The Revised Oxford Translation. Princeton: Princeton University Press.

Borisonik, H. (2013). Dinero sagrado. Política, economía y sacralidad en Aristóteles. Madrid / Buenos Aires: Miño y Dávila.

Bücher, K. (1893). Die Entstehung der Volkswirtschaft, Tubinga: H. Laupp’schen. [Online] Available: http://www.deutschestextarchiv.de/book/view/buecher_volkswirtschaft_1893?p=1 (May 19, 2016)

Burke, E. (1992). The economy of Athens in the classical era: Some adjustments to the primitivist model. Transactions of the American Philological Association, 122. DOI: $10.2307 / 284371$

Finley. M. I. (1970). Aristotle and Economic Analysis. Past \& Present, 47, Oxford University Press. DOI:10.1093/past/47.1.3

Hasebroek, J. (1928). Staat und Handel im alten Griechenland. Tubinga: Mohr.

Marx, K. (2005 [1867]). Capital: A Critique of Political Economy. 3 Vols, by Karl Marx. Ed. Federick Engels. Trans. From the 1st German edition by Ernest Untermann. Chicago: Charles H. Kerrand Co. Cooperative.

Meikle, S. (1979). Aristotle and the political economy of the polis. The Journal of Hellenic Studies, 99, University of Glasgow. DOI: 10.2307/630632

Meikle, S. (1995). Aristotle's economic thought. Oxford: Clarendon Press.

Meyer, E. (1924). Die wirtschaftliche Entwicklung des Altertums [1895], Kleine Schriften, v. 1. Halle: Niemeyer.

Polanyi, K., Arensberg, C., Pearson, H. (Eds.) (1957). Trade and Market in the Early Empires: 
Economies in History and Theory. New York: The Free Press.

Rodbertus, J. K. (1899). “Economic life in classical antiquity”, Schriften. Berlin: Puttkammer \& Mühlbrecht.

Rostovtzeff, M. (1941). A Social and Economic History of the Hellenistic World. New York: Oxford University Press.

Schumpeter, J. A. (1959). History of economic analysis. New York: Oxford University Press.

Soudek, J. (1952). Aristotle's theory of exchange - An inquiry into the origin of the economic analysis. Proceedings of the American Philosophical Society, 96.

Will, E. (1954a). De l'aspect éthique des origines grecques de la monnaie. Revue Historique, CCXII, 2.

Will, E. (1954b). Trois quartes de siècle de recherches sur l'économie grecque antique. Les Annales, 19.

\section{Copyright Disclaimer}

Copyright for this article is retained by the author(s), with first publication rights granted to the journal.

This is an open-access article distributed under the terms and conditions of the Creative Commons Attribution license (http://creativecommons.org/licenses/by/3.0/). 